\title{
EFFECT OF FERTILIZER AND MANURE APPLICATION ON SOIL ORGANIC CARBON SEQUESTRATION, SOIL FERTILITY AND YIELD SUSTAINABILITY UNDER MAIZE-WHEAT CROPPING SYSTEM IN SUBTROPICAL MOLLISOLS
}

\author{
Veer Singh $^{1}$, Amit Bhatnagar ${ }^{2}$, Anil Kumar Pant ${ }^{1}$, Ajaya Srivastava ${ }^{1}$, S. P. Gangwar ${ }^{1}$ \\ ${ }^{1}$ Department of Soil Science, College of Agriculture, G.B. Pant University of Agriculture \& Technology, Pantnagar, U.S. Nagar-263145, Uttarakhand, India. \\ ${ }^{2}$ Department of Agronomy, College of Agriculture, G.B. Pant University of Agriculture \& Technology, Pantnagar, U.S. Nagar-263145, Uttarakhand, India.
}

Received - June 01, 2020; Revision - July 30, 2020; Accepted - August 07, 2020

Available Online - August 25, 2020

DOI: http://dx.doi.org/10.18006/2020.8(4).390.401

KEYWORDS
Fertilizers
FYM
Maize-wheat rotation
Yield
Soil fertility
Soil organic carbon
sequestration
Mollisols

\begin{abstract}
A field experiment with nine treatments was initiated in 2014 on a Mollisol to study the effect of fertilizers (NPK) and farmyard manure (FYM) application with or without Azotobector or Zinc on yields, soil organic carbon (SOC) storage and sequestration and soil properties in maize-wheat rotation. After four years it was revealed that continuous application of 100\% recommended dose of NPK+ FYM @ $5 \mathrm{t} \mathrm{ha}^{-1}$ recorded significantly higher grain yields of maize and wheat and N, P, and $\mathrm{K}$ removal by the system. Crops yield increased by $100 \%$ NPK alone or combined with FYM or Zn in the fourth year compared to the first year. Intercropping of cowpea with maize caused a reduction in maize yield but its residual effect enhanced wheat yield. Bulk density of surface soil reduced significantly from 1.4-4.3\% over initial except in control and 50\% NPK. Available N, P, K, and Zn increased under integrated use of NPK fertilizer and FYM or Zn but decreased more in control. Response to the application of $100 \%$ NPK was maximum to the tune of 1.31 $\mathrm{t} \mathrm{ha}^{-1}$ for maize and $1.34 \mathrm{t} \mathrm{ha}^{-1}$ for wheat whereas least with cowpea intercropping. SOC content and storage/pool in the surface soil increased from $0.7-7.2 \%$ and $0.5-2.9 \%$, respectively, in FYM applied plots over the initial level. Application of FYM @ $10 \mathrm{t}$ ha + Azotobacter in cowpea intercropping sequestrated maximum SOC ( $0.14 \mathrm{Mg} \mathrm{C}$ ha $\left.^{-1} \mathrm{yr}^{-1}\right)$ but reduced yields of maize and wheat. Grain yield of maize rather than wheat was more closely correlated with SOC content and storage. Results suggested that continuous application of 100\% NPK along with FYM @ $5 \mathrm{t} \mathrm{ha}^{-1}$ led to better soil fertility and yield sustainability.
\end{abstract}

* Corresponding author

E-mail: veer1969_singh@yahoo.co.in (Veer Singh)

Peer review under responsibility of Journal of Experimental Biology and Agricultural Sciences.

Production and Hosting by Horizon Publisher India [HPI] (http://www.horizonpublisherindia.in/).

All rights reserved.
All the articles published by Journal of Experimental Biology and Agricultural Sciences are licensed under a Creative Commons Attribution-NonCommercial 4.0 International License Based on a work at www.jebas.org.

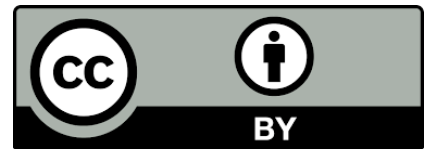




\section{Introduction}

The plain zone of state Uttarakhand known as Tarai falls under order Mollisols and covers an area of about 1.6 million hectares which is more fertile. The soils in the Tarai region have a wet moisture regime and shallow water table for most time of the year and are poorly drained in the low lying areas. Tarai soils have been brought under cultivation on the recently removed forested ecosystem in late 1940 after clearing of dense forest and grasslands (Ram et al., 2016). Rice-wheat is the major cropping system for the past several decades in the Tarai region. Both crops are heavy nutrient feeders (Panwar et al., 2019). Moreover adaptation of high yielding and nutrient responsive varieties of these crops, as well as faulty agricultural practices by the farmers, are common in this area. Consequently overexploitation of the natural resources especially fertile land and plenty of available water created an adverse impact on the soil in the form of deterioration of soil health, fragile crop environment and, reduced profitability of crops (Ram et al., 2016). On the other hand, various researches had reported that manure application increases crop yields besides soil organic matter and improves soil quality as well (Blair et al., 2006; Yang et al., 2015). Inorganic fertilizers are the major inputs in the present agriculture system rather excessive and indiscriminate use led to the depletion of soil fertility and productivity (Dubey et al., 2012; Rahman \& Zhang, 2018). Naresh (2013) reported that under continuous and intensive farming, of rice-wheat cropping system, the nutrient supplying power of most of the soils has been found declining, therefore becoming less profitable consequently farmers are shifting to other profitable cropping systems. The maize-wheat cropping system occupies fifth place in Indo-Gangetic Plains of India (Yadav \& Subba Rao, 2001). Although maize is not a major cereal crop and grown only in 23 thousand hectares land of hill and plain area of Uttarakhand (Annual Progress Report, IIMR, 2016) however, farmers of tarai region are showing their interest in this crop due to its multipurpose use and higher profitability. Maize could be a suitable substitute for rice and fits well in the maizewheat cropping system, yet careful nutrient management is the prerequisite for the successful cultivation of hybrid maize. Continuous application of chemical fertilizer for a long time may give rise to soil fertility related problems. Many long-term soil fertility experiments on various cropping systems draw attention to soil fertility (Manna et al., 2005; Sharma et al., 2019) but little information is available on the consequences of long-term soil fertility management on the productivity of maize-wheat systems in Asia. In hilly areas of Uttarakhand, the average utilization of inorganic fertilizers is $8-10 \mathrm{~kg} \mathrm{ha}^{-1}$ as compared to the plain region $\left(200 \mathrm{~kg} \mathrm{ha}^{-1}\right)$. Among the organic sources, farmyard manure is the most important as it contains all the nutrients needed for crop growth including trace elements, albeit in small quantities (Achieng et al., 2010). Continual applications of FYM not only supply plant nutrients to the crop but also increase the soil organic matter and improve soil water holding capacity (Mongare et al., 2020). Many long-term studies reported that the application of FYM considerably increased the maize yield in different maizelegume intercropping systems (Saini \& Kumar, 2014; Ndiso et al., 2018). Azotobacter, a free-living $\mathrm{N}_{2}$ fixing bacterium contributes to nitrogen in many non-leguminous crops such as wheat, maize, rice, sugarcane, etc. without causing damage to the environment as well as soil. Besides nitrogen fixation, Azotobacter also synthesizes and secretes a considerable amount of biologically active substances which enhances root growth and protects the plant from diseases (Soleimanzadeh \& Gooshchi, 2013). The increase in grain yield of crops is higher when inoculation is done without the use of chemical fertilizer (Baral \& Adhikari, 2013). The addition of external organic sources in the field is the common practice for the farmers of hilly areas while in plain areas it is rarely applied by the farmers. Considering the declining soil fertility and productivity, reduced profitability, ecological disturbance, etc. prolonged excessive and indiscriminate the uses of chemical fertilizers and intensive farming system, the present investigation was undertaken to investigate the effect of the use of fertilizers and organic manure in integrated mode or alone in the maize-wheat cropping system.

\section{Materials and Methods}

\subsection{Site description}

A field experiment was initiated in kharif 2014 at the Norman E. Borlaug Crop Research Centre of the Govind Ballabh Pant University of Agriculture and Technology, Pantnagar, Uttarakhand situated at $28^{\circ} 58^{\prime}-29^{\circ} 1$ ' $\mathrm{N}$ latitude and $79^{\circ} 24^{\prime}-79^{\circ} 31^{\prime} \mathrm{E}$ longitude. The climate of the area is humid sub-tropical with an annual rainfall of $1,433 \mathrm{~mm}$, of which, more than $85 \%$ is received during the wet season (June to September). The mean maximum temperature may go up to the $43^{\circ} \mathrm{C}$ in May during summer and a minimum below $2{ }^{0} \mathrm{C}$ in January during winter. The monthly distribution of precipitation, air temperature, and relative humidity prevailed at the study site during 2014-2017 is presented in Figure 1. The soils of the research center are classified as fine mixed hyperthermic Aquic Hapludoll (Deshpande et al., 1971b). The experimental soil (sandy loam, sand-52\%, silt- $32.0 \%$ and caly$16.0 \%$ ) was neutral in reaction (6.92), low in salt content $0.18 \mathrm{dS}$ $\left.\mathrm{m}^{-1}\right)$, available $\mathrm{N}\left(187.9 \mathrm{~kg} \mathrm{ha}^{-1}\right)$ and $\mathrm{Zn}\left(0.47 \mathrm{mg} \mathrm{kg}^{-1}\right)$, high in organic carbon $(0.95 \%)$ and medium in available $\mathrm{P}\left(24.5 \mathrm{~kg} \mathrm{ha}^{-1}\right)$ and $\mathrm{K}\left(152.6 \mathrm{~kg} \mathrm{ha}^{-1}\right)$.

\subsection{Experimental design and treatments}

The experiment was laid out in a randomized block design with three replications. The size of each plot was $9.0 \mathrm{~m} \times 15.0 \mathrm{~m}$ and had 15 and 40 rows of maize and wheat, respectively. There were 9 treatments. In the maize crop, the experimental treatments were as 


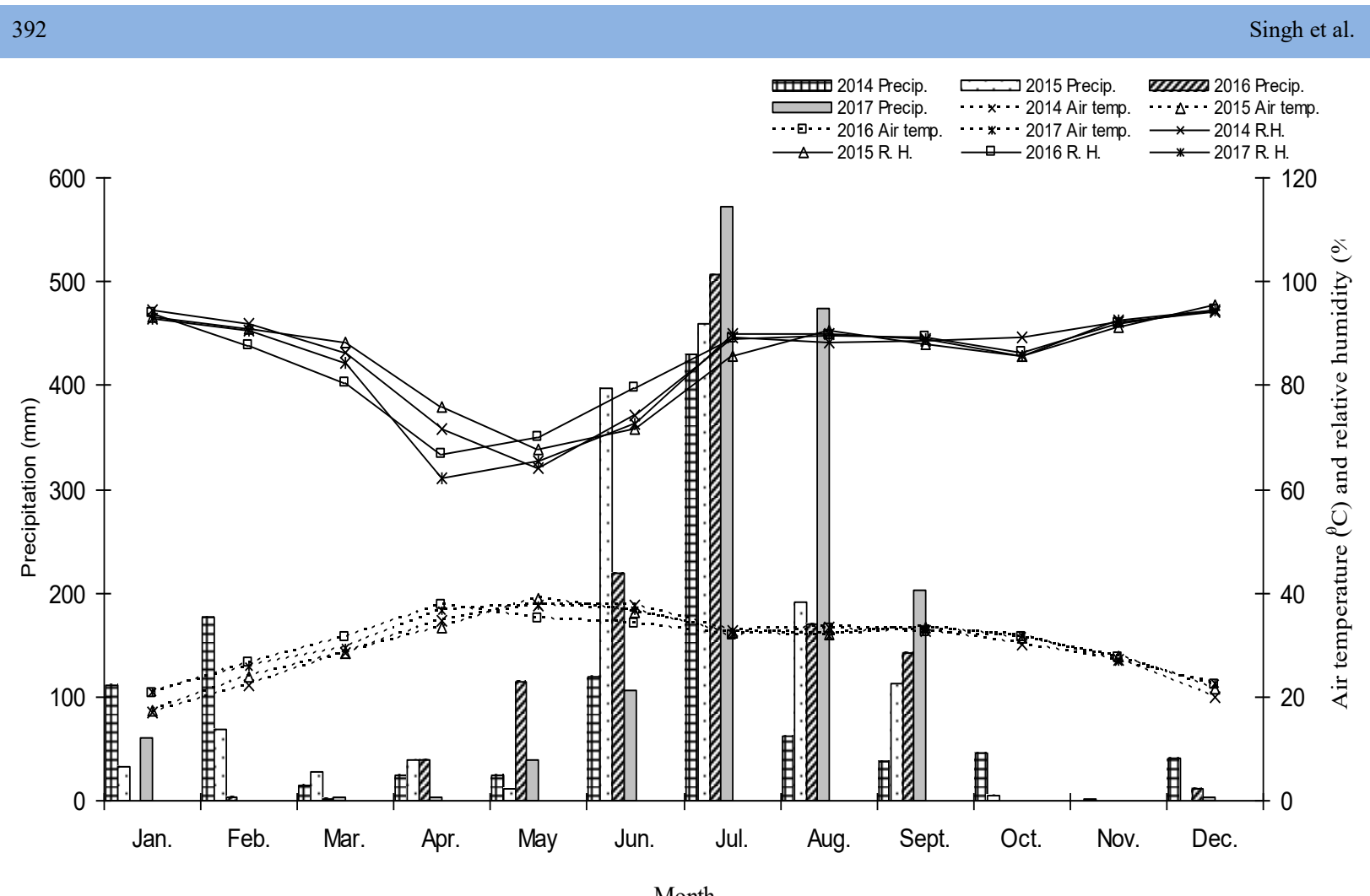

Month

Figure1 Monthly distribution of precipitation, relative humidity and air temperature during the 2014 to 2017 existing for maize and wheat crops during growing period

follows: $100 \%$ recommended dose of fertilizers (RDF) $(120,60,40$ kg N, $\mathrm{P}_{2} \mathrm{O}_{5}, \mathrm{~K}_{2} \mathrm{O}$ ha $\left.^{-1}\right) ; 50 \%$ RDF; FYM @ 10 tha $^{-1}+$ Azotobacter; Maize + cowpea with FYM @ $10 \mathrm{t} \mathrm{ha}^{-1}+$ Azotobacter; 100\% RDF + FYM@ $5 \mathrm{t} \mathrm{ha}^{-1} ; 50 \%$ RDF + FYM@ $5 \mathrm{t} \mathrm{ha}^{-1} ; 100 \%$ RDF + Zn@ $5 \mathrm{~kg} \mathrm{ha}^{-1}$; and FYM@5 tha $\mathrm{t}^{-1}$ (state hill practice) and no fertilizer and farmyard manure (control). In maize crop, treatments FYM @ $10 \mathrm{t} \mathrm{ha}^{-1}+$ Azotobacter; Maize + cowpea with FYM @ $10 \mathrm{t} \mathrm{ha}^{-1}+$ Azotobacter and FYM@ $5 \mathrm{t} \mathrm{ha}^{-1}$ received nutrients through organic mode while in other treatments thorough inorganic alone or combination with FYM. However, in case of the wheat crop, 100\% $\mathrm{RDF}\left(150,60,40 \mathrm{~kg} \mathrm{~N}, \mathrm{P}_{2} \mathrm{O}_{5}, \mathrm{~K}_{2} \mathrm{O} \mathrm{ha}^{-1}\right)$ was applied only in those treatments where NPK was supplied through inorganic fertilizers in the maize crop but in the other treatments (FYM @ $10 \mathrm{t} \mathrm{ha}^{-1}+$ Azotobacter; Maize + cowpea with FYM @ $10 \mathrm{tha}^{-1}+$ Azotobacter and FYM@ $5 \mathrm{t} \mathrm{ha}^{-1}$ ), similar doses of FYM only in the respective treatments were incorporated as given in maize crop. Control did not receive any inorganic fertilizers or FYM in both crops. Cowpea was intercropped as a grain crop in between the rows of maize crops only. Azotobacter was inoculated with maize seeds only.

\subsection{Agronomic practices}

The sources of $\mathrm{N}, \mathrm{P}, \mathrm{K}$, and $\mathrm{Zn}$ were urea, single super phosphate, muriate of potash, and zinc sulfate, respectively.
Applied FYM varied in their nutrients content from $0.45-0.9 \%$ $\mathrm{N}, 0.3-0.42 \% \mathrm{P}$, and $0.45-0.55 \% \mathrm{~K}$ and $0.002-0.004 \% \mathrm{Zn}$ on dry weight basis. Before sowing both of the crops, one-third dose of $\mathrm{N}$ and a full dose of $\mathrm{P}, \mathrm{K}, \mathrm{Zn}$, and fully decomposed FYM were mixed properly in soil and remaining $\mathrm{N}$ was given in two equal splits by top dressing at the knee-high stage and tassel emergence in maize and first irrigation and at the time of panicle initiation in wheat. Pioneer P 3396, UP 2565, and Pant Lobia-1 were the varieties of maize, wheat, and cowpea, respectively. Maize seeds were sown at a row spacing of $60 \mathrm{~cm}$ with the plant to plant spacing at $25 \mathrm{~cm}$ while in wheat row spacing was maintained at $22.5 \mathrm{~cm}$. Two rows of cowpea were sown at the spacing of $15 \mathrm{~cm}$ plant to plant between two rows of maize in an additive manner. Maize and cowpea were sown in the second fortnight of June and harvested in mid-October followed by the sowing of wheat during the second fortnight of November and harvested in midApril. Irrigation was given at the critical stages of the crops. The crops following standard agronomic practices did not face any damage due to insects and pests during their growing cycle. In both crops, weeds in the NPK fertilizers received plots were controlled manually and chemically however, FYM received plots were weeded manually. After the harvest of crops, the data for grain and stover/straw was recorded for the respective plots and presented accordingly. 


\subsection{Soil sampling and analysis}

The single composite soil sample was collected from the experimental site initially from topsoil ( $0-15 \mathrm{~cm}$ depth) and thereafter each year after the harvesting of wheat crop. Random samples (10 numbers) from the surface ( $0-15 \mathrm{~cm}$ depth) were collected from each plot and mixed well to obtain the composite sample for further soil analysis. The collected air-dried soil samples were grounded with a wooden roller and passed through $0.2 \mathrm{~mm}$ sieve for organic carbon and $2 \mathrm{~mm}$ sieve for other soil quality parameters. The samples were analyzed for soil $\mathrm{pH}$ and electrical conductivity (EC) in 1:2 soil: water suspension using $\mathrm{pH}$ and conductivity meter, respectively. Organic carbon by potassium dichromate oxidizing method (Jackson, 1973), oxidizable N by alkaline potassium permanganate method (Subbiah \& Asija, 1956), available $\mathrm{P}$ by extraction with $0.5 \mathrm{M}$ sodium bicarbonate $(\mathrm{pH} 8.5)$ and determined using an ascorbic acid method (Olsen et al., 1954), available potassium with neutral ammonium acetate (Hanway \& Heidel, 1952) followed by emission spectrometry and available $\mathrm{Zn}$ with DTPA-extraction using spectrophotometer (Lindsay \& Norvell, 1978). The bulk density of soil was measured by the core method (Blake \& Hartze, 1986). The soil organic carbon pool for the surface soil was estimated using the following formula (Chaudhary et al., 2017):

SOC pool $\left(\mathrm{Mg} \mathrm{ha}^{-1}\right)=\operatorname{SOC}(\%) \times$ soil depth $(\mathrm{m}) \times \mathrm{Db}\left(\mathrm{Mg} \mathrm{m}^{-3}\right)$ $\times 10^{4}\left(\mathrm{~m}^{2} \mathrm{ha}^{-1}\right) \times 10^{-2}$

Soil carbon sequestration rate was calculated as per the equation given by Brar et al. (2015):

Soil carbon sequestration rates $\left(\mathrm{Mg} \mathrm{C} \mathrm{ha}{ }^{-1}\right.$ year $\left.^{-1}\right)=(\mathrm{SOCPi}-$ SOCPo)/T

Where $\mathrm{Db}$ is bulk density, SOCPi is soil organic carbon pool at the time of last wheat crop harvest, SOCPo is the initial soil organic carbon pool at the time of the start of the experiment and $\mathrm{T}$ is total years of experiment.

\subsection{Plant sampling and analysis}

Grain and straw samples of crops were collected from each plot over the years after harvesting then processed and digested in the tri-acid mixture and total content of $\mathrm{N}, \mathrm{P}, \mathrm{K}$, and $\mathrm{Zn}$ were estimated using standard procedures (Jackson, 1973). The nutrient uptake by crops was computed by multiplying the content of the specific element with their air-dried grain and straw yields. The total nutrient uptake for the maize-wheat system was calculated as the sum of nutrients harvested in both crops

\subsection{Data analysis}

Analysis of data was carried through analysis of variance prescribed for RBD and significant differences between the treatments were evaluated at $\mathrm{P}<0.05$. The regression line of crop yields to soil organic carbon and regression equations for different fertilizer and FYM treatments were computed using Microsoft Excel 2010.

\section{Results and Discussion}

\subsection{Effect of chemical fertilizers and FYM on soil properties}

The experimental results revealed that soil reaction and salts content did not get influence significantly the treatments (Table 1). However, soil reaction was found slightly alkaline ranging from 7.04-7.10 $\mathrm{pH}$ and rose by 0.12-0.25 units in the NPK fertilizer applied treatments and control but lowered in FYM applied plots in both the crops. The

Table 1 Soil characteristics in the surface soil $(0-15 \mathrm{~cm})$ after 4 years application of fertilizer and manure in a maize-wheat cropping system

\begin{tabular}{|c|c|c|c|c|c|c|c|}
\hline \multirow{2}{*}{ Treatment } & \multirow{2}{*}{$\begin{array}{c}\mathrm{pH} \\
(1: 2)\end{array}$} & \multirow{2}{*}{$\begin{array}{l}\text { Electrical conductivity } \\
\left(\mathrm{dS} \mathrm{m}^{-1}\right)\end{array}$} & \multirow{2}{*}{$\begin{array}{l}\text { Bulk density } \\
\left(\mathrm{Mg} \mathrm{m}^{-3}\right)\end{array}$} & \multicolumn{4}{|c|}{ Available nutrients $\left(\mathrm{kg} \mathrm{ha}^{-1}\right)$} \\
\hline & & & & $\mathrm{N}$ & $\mathrm{P}$ & $\mathrm{K}$ & $\mathrm{Zn}$ \\
\hline $\mathrm{NPK}^{*}$ & $7.06^{\mathrm{abc}}$ & $0.19^{\mathrm{ab}}$ & $1.38^{\mathrm{bc}}$ & $184.1^{\mathrm{abc}}$ & $25.5^{\mathrm{b}}$ & $153.4^{\mathrm{b}}$ & $0.452^{\mathrm{bc}}$ \\
\hline $\mathrm{NPK}^{* *}$ & $7.09^{\mathrm{a}}$ & $0.20^{\mathrm{a}}$ & $1.40^{\mathrm{ab}}$ & $180.1^{\mathrm{c}}$ & $23.3^{\mathrm{cd}}$ & $148.3^{\mathrm{d}}$ & $0.444^{\text {cd }}$ \\
\hline $\mathrm{FYM}^{*+}$ Azotobacter & $6.95^{\mathrm{abc}}$ & $0.17^{\mathrm{ab}}$ & $1.35^{\mathrm{de}}$ & $178.3^{\text {cd }}$ & $22.5^{\mathrm{de}}$ & $146.1^{\mathrm{e}}$ & $0.429^{\mathrm{de}}$ \\
\hline $\begin{array}{l}\text { Cowpea with FYM* } \\
\text { Azotobacter }\end{array}$ & $6.91^{\mathrm{c}}$ & $0.16^{\mathrm{b}}$ & $1.34^{\mathrm{e}}$ & $181.3^{\mathrm{c}}$ & $22.9^{\mathrm{d}}$ & $147.2^{\mathrm{de}}$ & $0.434^{\mathrm{d}}$ \\
\hline $\mathrm{NPK}^{*+\mathrm{FYM}^{* *}}$ & $7.04^{\mathrm{abc}}$ & $0.17^{\mathrm{ab}}$ & $1.36^{\mathrm{cde}}$ & $187.2^{\mathrm{a}}$ & $27.1^{\mathrm{a}}$ & $156.9^{\mathrm{a}}$ & $0.463^{\mathrm{b}}$ \\
\hline $\mathrm{NPK}^{* *+\mathrm{FYM}^{* *}}$ & $7.05^{\mathrm{abc}}$ & $0.18^{\mathrm{ab}}$ & $1.37^{\text {cd }}$ & $182.6^{\mathrm{bcd}}$ & $24.7^{\mathrm{bc}}$ & $151.0^{\mathrm{c}}$ & $0.450^{\mathrm{bc}}$ \\
\hline $\mathrm{NPK}^{*}+5 \mathrm{~kg} \mathrm{Zn}$ & $7.07^{\mathrm{ab}}$ & $0.19^{\mathrm{ab}}$ & $1.38^{\mathrm{c}}$ & $185.4^{\mathrm{ab}}$ & $25.2^{\mathrm{b}}$ & $152.8^{\mathrm{b}}$ & $0.479^{\mathrm{a}}$ \\
\hline FYM** & $6.94^{\mathrm{bc}}$ & $0.17^{\mathrm{ab}}$ & $1.37^{\mathrm{c}}$ & $176.4^{\mathrm{d}}$ & $21.9^{\mathrm{de}}$ & $144.4^{\mathrm{e}}$ & $0.425^{\mathrm{e}}$ \\
\hline Control & $7.10^{\mathrm{a}}$ & $0.20^{\mathrm{a}}$ & $1.42^{\mathrm{a}}$ & $175.7^{\mathrm{d}}$ & $21.2^{\mathrm{e}}$ & $142.4^{\mathrm{f}}$ & $0.415^{\mathrm{e}}$ \\
\hline Initial & 6.92 & 0.18 & 1.40 & 187.9 & 24.5 & 152.6 & 0.472 \\
\hline $\operatorname{SEm} \pm$ & 0.04 & 0.01 & 0.01 & 1.00 & 0.5 & 0.6 & 0.005 \\
\hline $\mathrm{LSD}_{0.05}$ & NS & NS & 0.02 & 2.99 & 1.4 & 1.8 & 0.015 \\
\hline
\end{tabular}

NPK*- 100\% NPK, NPK**- 50\% NPK, FYM*-FYM 10 t ha $^{-1}$, FYM $^{* *}$ - FYM 5 t ha $^{-1}$

Journal of Experimental Biology and Agricultural Sciences

http://www.jebas.org 
decline in $\mathrm{pH}$ under FYM alone plots could have resulted from the build-up of organic matter which releases hydrogen ions during decomposition (Pareek \& Yadav, 2011). A similar trend for electrical conductivity as found for soil reaction was noted among the treatments. Soil bulk density was found to be significantly affected under different treatments over the years (Zhang et al., 2006) and reduced from 0.4$0.06 \mathrm{Mg} \mathrm{m}^{-3}$ under sole FYM received plots over initial but increased non-significantly in others. A decrease in soil bulk density is mainly attributed to higher organic matter content due to FYM and more root and plant biomass addition into the soil which results in better aggregation of soil separates and a consequent increase in the volume of micropores (Tripathi et al., 2014). Raising the NPK fertilizers from sub-optimal to optimal levels with or without FYM and cowpea intercropping did not significantly influence this property. Availability of N, P, and K found to be highest with conjoint use of $100 \%$ NPK and FYM (Kang et al., 2005; Meena et al., 2017), while lowest under control. Compared to the initial status of N, P, and K, only balance use of chemical fertilizers and FYM could maintain the higher availability of P and K which found to remain at par with 100\% NPK + FYM @ 5 $\mathrm{t} \mathrm{ha}^{-1}$ however reduced significantly in other practices. The greater availability of $\mathrm{N}$ with combined application of $100 \%$ NPK and FYM (a) $5 \mathrm{t} \mathrm{ha}^{-1}$ may be due to higher addition of organic matter through FYM and root as well as plant biomass, which might have helped in the multiplication of soil microbes, ultimately enhancing the conversion of organically bound $\mathrm{N}$ to mineral form (Tolanur \& Badanur, 2003). Regular addition of an optimum dose of phosphates fertilizer in both crops as well as FYM may help in solubilizing the native $\mathrm{P}$ at a greater rate in the soil through the release of various organic acids (Tiwari, 2003) and organic ions compete with the phosphate ions for binding sites on soil particles, thereby reducing the P fixation (Panneerselvam et al., 2000) and reduction in K fixation and release of $\mathrm{K}$ ions due to the interaction of organic matter with clay (Urkurkar et al., 2010). Increasing the NPK dose from 50 to $100 \%$ with or without FYM significantly enhanced $\mathrm{N}, \mathrm{P}$, and $\mathrm{K}$ availability from 4.6, 2.4 and 5.9 and 4.1, 2.2 and $5.1 \mathrm{~kg} \mathrm{ha}^{-1}$, respectively, however intercropping of cowpea with maize along with FYM+ Azotobacter over FYM + Azotobacter and $\mathrm{Zn}$ addition over $100 \%$ NPK gave at par availability. Addition of Zn @ $5 \mathrm{~kg} \mathrm{ha}^{-1}$ along with 100\% NPK recorded the greatest availability of $\mathrm{Zn}$ followed by $100 \% \mathrm{NPK}+\mathrm{FYM}$ (a) $5 \mathrm{t} \mathrm{ha}^{-1}$ whereas control arrested the greatest reduction. Availability of DTPA extractable Zn enhanced by 1.5\% in 100\% NPK + Zn @ $5 \mathrm{Kg} \mathrm{ha}^{-1}$ but remained at par with 100\% NPK + FYM @ 5t ha ${ }^{-1}$ however depleted from $4.2-12.1 \%$ in other treatments over the initial level of $0.472 \mathrm{~kg} \mathrm{ha}^{-1}$. The increase in $\mathrm{Zn}$ availability could be attributed to direct and continuous application of $\mathrm{Zn}$ in the soil as well as mineralization of organically bound forms of $\mathrm{Zn}$ in the FYM (Kher, 1993) whereas reduction could be attributed to more removal of $\mathrm{Zn}$ under intensive crop production system. Comparing the increase in nutrients availability between treatments 100\% NPK and 50\% NPK, FYM@10 t ha ${ }^{-1}+$ Azotobacter and cowpea with FYM @ $10 \mathrm{t} \mathrm{ha}^{-1}+$ Azotobactor, 100\% NPK + FYM @ $5 \mathrm{t} \mathrm{ha}^{-1}$ and 50\% NPK + FYM @ $5 \mathrm{t} \mathrm{ha}^{-1}, 100 \%$ NPK and 100\% NPK + 5kg Zn and FYM @ $5 \mathrm{t} \mathrm{ha}^{-1}$ and Control , maximum increase of N, P and K was recorded for 100\% $\mathrm{NPK}+\mathrm{FYM} @ 5 \mathrm{t} \mathrm{ha}^{-1}$ and 50\% NPK + FYM @5 $\mathrm{t} \mathrm{ha}^{-1}$ and $\mathrm{Zn}$ for $100 \% \mathrm{NPK}$ and $100 \% \mathrm{NPK}+5 \mathrm{~kg} \mathrm{Zn}$.

\subsection{Effect of chemical fertilizers and FYM on SOC storage and sequestration}

Over four years of continuous application of NPK fertilizer and FYM alone or in combinations significantly affected the content, pool/stock, and sequestration rate of SOC in the surface soil (Table 2). SOC

Table 2 Soil organic carbon (SOC) dynamics at the surface soil $(0-15 \mathrm{~cm})$ after 4 years application of fertilizer and manure in maize-wheat cropping system

\begin{tabular}{|c|c|c|c|c|}
\hline Treatment & $\begin{array}{l}\mathrm{SOC} \\
(\mathrm{g} / \mathrm{kg})\end{array}$ & $\begin{array}{c}\text { SOC pool } \\
\left(\mathrm{Mg} \mathrm{C} \mathrm{ha}^{-1}\right)\end{array}$ & $\begin{array}{l}\text { SOC sequestration over } \\
\text { initial }\left(\mathrm{Mg} \mathrm{C} \mathrm{ha}^{-1}\right)\end{array}$ & $\begin{array}{l}\text { SOC sequestration rate } \\
\left(\mathrm{Mg} \mathrm{Cha}^{-1} \mathrm{yr}^{-1}\right)\end{array}$ \\
\hline $\mathrm{NPK}^{*}$ & $9.57^{\mathrm{g}}$ & $19.85^{\text {cde }}$ & $-0.097^{\mathrm{def}}$ & $-0.025^{\mathrm{def}}$ \\
\hline NPK** & $9.42^{\mathrm{h}}$ & $19.83^{\mathrm{de}}$ & $-0.123^{\mathrm{f}}$ & $-0.031^{\text {ef }}$ \\
\hline FYM $^{*+}$ Azotobacter & $10.04^{\mathrm{b}}$ & $20.29^{\mathrm{ab}}$ & $0.337^{\mathrm{ab}}$ & $0.084^{\mathrm{ab}}$ \\
\hline Cowpea with FYM* + Azotobacter & $10.18^{\mathrm{a}}$ & $20.52^{\mathrm{a}}$ & $0.567 \mathrm{a}$ & $0.142^{\mathrm{a}}$ \\
\hline $\mathrm{NPK}^{*+\mathrm{FYM}^{* *}}{ }^{* *}$ & $9.88^{\mathrm{c}}$ & $20.21^{\mathrm{b}}$ & $0.260^{\mathrm{b}}$ & $0.065^{\mathrm{b}}$ \\
\hline $\mathrm{NPK}^{* *+\mathrm{FYM}^{* *}}$ & $9.80^{\mathrm{de}}$ & $20.09^{\mathrm{bc}}$ & $0.143^{\text {bcd }}$ & $0.035^{\mathrm{bc}}$ \\
\hline $\mathrm{NPK}^{*+}+5 \mathrm{~kg} \mathrm{Zn}$ & $9.61^{\mathrm{fg}}$ & $19.90^{\text {cd }}$ & $-0.053^{\mathrm{ce}}$ & $-0.013^{\text {cde }}$ \\
\hline $\mathrm{FYM}^{* *}$ & $9.75^{\mathrm{e}}$ & $20.04^{\text {bcd }}$ & $0.090^{\text {bcde }}$ & $0.023^{\text {bcde }}$ \\
\hline Control & $9.23^{\mathrm{i}}$ & $19.62^{\mathrm{e}}$ & $-0.332^{\mathrm{f}}$ & $-0.083^{f}$ \\
\hline Initial & 9.50 & 19.95 & - & - \\
\hline $\mathrm{SEm} \pm$ & 0.03 & 0.08 & 0.078 & 0.019 \\
\hline $\mathrm{LSD}_{0.05}$ & 0.096 & 0.23 & 0.233 & 0.059 \\
\hline
\end{tabular}

Journal of Experimental Biology and Agricultural Sciences

http://www.jebas.org 
content was recorded maximum under 100\% NPK+ FYM @ 5t ha ${ }^{-1}$ which was recorded $1.4-8.1 \%$ significantly higher over other treatments (Rasool et al., 2008). Compared with initial SOC content, 50\% NPK, FYM @ $5 \mathrm{t} \mathrm{ha}^{-1}$ and control reduced SOC from $0.8-2.8 \%$ while in other treatments it enhanced from $0.7-7.2 \%$. Moreover, FYM incorporated plots led to significant changes in SOC over the initial SOC content. More increase in SOC under FYM applied treatments for four years was due to the addition of carbon through FYM, root biomass, and crop residue (Brar et al., 2015). Inclusion of NPK without FYM from 50 to $100 \%$ significantly enhanced SOC however on the other side increasing NPK with FYM@5t ha ${ }^{-1}$ had no significant effect on SOC accumulation during four years of maize-wheat rotation. The effect of different combinations of NPK fertilizer and FYM on the SOC pool showed a similar trend to that of SOC content. After four years, the SOC pool ranged from $19.62 \mathrm{Mg} \mathrm{C}^{-1}$ for control to $20.52 \mathrm{Mg} \mathrm{C}^{-1} \mathrm{f}^{-1}$ for cowpea intercropped maize with FYM @ 10t $\mathrm{ha}^{-1}+$ Azotobacter. Continuous application of FYM either alone or along with NPK fertilizer increased the SOC pool from 20.04 $20.52 \mathrm{Mg} \mathrm{C}^{-1}$ over the initial level of $19.95 \mathrm{Mg} \mathrm{C}$ ha however it decreased from $0.05-0.12 \mathrm{Mg} \mathrm{C} \mathrm{ha}^{-1}$ in other treatments. An increase in $50 \%$ NPK with our without FYM, intercropping of cowpea, and inclusion of zinc did not enhance a significant amount of SOC storage. FYM received plots increased the SOC sequestration from $0.023-0.142 \mathrm{Mg} \mathrm{Cha}^{-1} \mathrm{yr}^{-1}$, on the other hand, the loss was obtained in other treatments. Application of FYM @ $10 \mathrm{tha}^{-1}+$ Azotobacter with cowpea intercropping sequestrated the highest SOC (0.142 Mg C ha $\left.{ }^{-1} \mathrm{yr}^{-1}\right)$ followed by FYM @ $10 \mathrm{t} \mathrm{ha}^{-1}+$ Azotobacter while the maximum was obtained under controlled condition (-0.083 $\left.\mathrm{Mg} \mathrm{C} \mathrm{ha}^{-1} \mathrm{yr}^{-1}\right)$. Organic manures contain most carbon in recalcitrant forms resulting in more carbon sequestration as it had already gone under some decomposition before application in agricultural fields (Benbi \& Senapati, 2009).

\subsection{Effect of chemical fertilizers and FYM on maize grain yield}

The data on the maize grain yield in the initial year (2014), fourthyear (2017), and the average yield over the years (2014-17) are presented in Table 3. In the initial year of experiment grain yield of maize under different organic, inorganic, and integrated mode varied from 4.59-5.33 $\mathrm{t} \mathrm{ha}^{-1}$. Among the treatments, the lowest grain yield was recorded with control $\left(4.23 \mathrm{t} \mathrm{ha}^{-1}\right)$ whereas significantly superior yield was noticed under $100 \%$ NPK + FYM (a) 5t ha ${ }^{-1}$ treatment which produced 0.13-1.1 $\mathrm{t} \mathrm{ha}^{-1}$ higher yield over others except $100 \% \mathrm{NPK}+5 \mathrm{~kg} \mathrm{Zn}$. Changing the dose of NPK fertilizer from 50 to $100 \%$ either alone or conjoint with FYM significantly enhanced maize grain yield from 5.3-8.0\%. However, an increase in yield was found less when NPK fertilizers dose increased alone as compared to FYM. Less difference in yields between 100\% NPK +FYM@ @ $5 \mathrm{t} \mathrm{ha}^{-1}$ and 50\% NPK + FYM @ 5 $\mathrm{t} \mathrm{ha}^{-1}$ might be attributed to the balanced nutrient supply by FYM which provides the essential nutrients as well as induced the availability of nutrients to crops during the growth period (Meena et al., 2017). Maize grown with either organic or inorganic mode of nutrients inclusion produced significantly lower yield compared with the integrated application of nutrients. However, sole maize crop yielded higher than maize + cowpea intercropping under FYM with Azotobacter application (Takim, 2012; Hamd Alla et al., 2014). Application of FYM @5t ha ${ }^{-1}$ and Zn @ $5 \mathrm{~kg} \mathrm{ha}^{-1}$ increased maize yield marginally by 4.3 and $1.8 \%$, respectively, over $100 \%$ NPK. In the fourth year yield trend among the different fertilizer and FYM management practices in general found similar to the initial year. Comparing with respective treatments of the initial year, a slight reduction in yield from $0.12-0.56 \mathrm{t} \mathrm{ha}^{-1}$ could be observed in the treatments 50\% NPK, FYM @ $10 \mathrm{t} \mathrm{ha}^{-1}+$ Azotobacter, Cowpea with FYM @ $10 \mathrm{t} \mathrm{ha}^{-1}+$ Azotobacter, FYM (a) $5 \mathrm{t} \mathrm{ha}^{-1}$ and Control where the highest and the least reduction in yield was recorded with control and FYM @ 10t ha ${ }^{-1}+$ Azotobactor with cowpea intercropping, respectively, but in the treatments $100 \%$ NPK, $100 \%$ NPK + FYM $5 \mathrm{t} \mathrm{ha}^{-1}, 50 \% \mathrm{NPK}+$ FYM @ $5 \mathrm{t} \mathrm{ha}^{-1}$ and 100\% NPK + 5 kg Zn maize yield enhanced from $0.10-0.22 \mathrm{t} \mathrm{ha}^{-1}$ with maximum under $100 \% \mathrm{NPK}+\mathrm{FYM}$ @ $10 \mathrm{t} \mathrm{ha}^{-1}$. The superiority of this treatment might be due to an adequate supply of macro and micronutrients through FYM. Inclusion of FYM and zinc led to enhance yield while organic mode (FYM@10 t ha ${ }^{-1}$, Cowpea with FYM @ $10 \mathrm{t} \mathrm{ha}^{-1}+$ Azotobacter and FYM@ $5 \mathrm{t} \mathrm{ha}^{-1}$ ) reduced yield over 100\% NPK. Although seed inoculation of Azotobacter and FYM applicationsupplied adequate $\mathrm{N}$ to crop (Peng et al., 2013) but medium $\mathrm{N}$ availability soil of tarai region without the addition of NPK fertilizer could not fulfill the nutrient requirement of maize crop. Four years (2014-17) mean yields revealed that incorporation of FYM@10t ha ${ }^{-1}$ or Zn@ $@ \mathrm{~kg} \mathrm{ha}^{-1}$ along with 100\% NPK could maintain significantly higher yield from 3.7-5.5\% over the recommended dose of fertilizer (100\% NPK) (Pillai et al., 2006; Kumari et al., 2013). Treatments FYM @ $10 \mathrm{t} \mathrm{ha}^{-1}+$ Azotobacter and Cowpea with FYM $10 \mathrm{t} \mathrm{ha}^{-1}+$ Azotobacter received a similar dose of FYM and Azotobacter, maize when intercropped with cowpea with FYM $10 \mathrm{t} \mathrm{ha}^{-1}+$ Azotobacter produced less but statistically at par yield showing the competition for nutrients and light interception by cowpea which resulted in a lower yield of maize (Egbe et al., 2010). Addition of FYM @ 5t ha ${ }^{-1}$ with 50\% NPK and $100 \%$ NPK enhanced yields by 6.0 and $5.6 \%$, respectively. This shows the more response of maize crop for the FYM at a lower dose of NPK fertilizers. Compared with control, applied NPK fertilizer and FYM either alone or in combinations produced $17.3-42.2 \%$ significantly higher grain yield of maize. Moreover, the use of FYM alone or in combination with Azotobacter or a suboptimal dose of NPK could not sustain the productivity of maize compared with $100 \%$ NPK alone or with FYM or zinc after four years of experiment. 


\subsection{Effect of chemical fertilizers and FYM on wheat grain yield}

Trends of wheat grain yield among the different treatments were noticed similar to the maize crop in the initial, fourth year, and over the years (Table 3 ). Wheat grain yields in the first year varied significantly from 3.54-4.82 $\mathrm{t} \mathrm{ha}^{-1}$ in the different treatments and highest in $100 \%$ NPK+ FYM @ $5 \mathrm{t} \mathrm{ha}^{-1}$ applied in maize crop while the lowest in control. Wheat crop received NPK $(100 \%$ NPK, 50\% NPK, 100\% NPK + FYM @ $5 \mathrm{t} \mathrm{ha}^{-1}, 50 \%$ NPK + FYM (a) $5 \mathrm{t} \mathrm{ha}^{-1}$ and $100 \% \mathrm{NPK}+5 \mathrm{~kg} \mathrm{Zn}$ ) resulted significantly higher grain yield as compared to sole FYM applied plots (FYM @ $10 \mathrm{t}$ $\mathrm{ha}^{-1}+$ Azotobacter, Cowpea with FYM@10 t ha ${ }^{-1}+$ Azotobacter and FYM@5 $\mathrm{t} \mathrm{ha}^{-1}$ ). Similarly, significant differences in wheat grain yield were recorded in between $50 \%$ and $100 \%$ NPK alone or with FYM applied plots and sole maize (FYM @ $10 \mathrm{t} \mathrm{ha}^{-1}+$ Azotobacter) and cowpea intercropped maize. The significantly higher yield of wheat under cowpea intercropped maize might be due to the inclusion of cowpea residue in the soil that helps to maintain and improve soil fertility as well as $\mathrm{N}$ fixation (Alla et al., 2014). In the fourth year, plots received $100 \%$ NPK in wheat except for $50 \%$ NPK increased wheat grain yield from $0.12-0.34 \mathrm{t}$ $\mathrm{ha}^{-1}$ while in the rest treatments yield declined from 0.12-0.0.30t $\mathrm{ha}^{-1}$ where a maximum increase was with the treatment receiving $100 \%$ NPK + FYM @ $5 \mathrm{t} \mathrm{ha}^{-1}$ in maize and maximum reduction in control. Despite receiving an optimal dose of NPK fertilizer in wheat (100\% NPK, 50\% NPK, 100\% NPK+FYM @ $5 \mathrm{t} \mathrm{ha}^{-1}$ and $50 \%$ NPK+FYM@ $5 \mathrm{t} \mathrm{ha}^{-1}$ ), wheat yields were found to be deferred significantly where NPK fertilizer increased from sub- optimal to an optimal level in maize. Similarly, the addition of FYM@ $9 \mathrm{t} \mathrm{ha}^{-1}$ over 50 or $100 \%$ NPK in maize produced a significantly higher yield of wheat. This might be attributed to the residual organic manure made through FYM applied in maize not only improved the physical properties of soil but also helped to make proper availability of nutrients to the succeeding wheat crop (Bi et al., 2009). Plots receiving nutrients only through inorganic way produced $0.71-0.82 \mathrm{t} \mathrm{ha}^{-1}$ higher grain yield of wheat than plots received FYM only. The residual impact of FYM @ $5 \mathrm{t} \mathrm{ha}^{-1}$ along with $100 \%$ NPK used in maize responded $0.41 \mathrm{t} \mathrm{ha}^{-1}$ more wheat grain yield as compared to the residual effect of FYM @ $5 \mathrm{t}$ $\mathrm{ha}^{-1}$ with $50 \%$ NPK which attracted towards the significance of FYM application with the optimal dose of NPK. Inclusion of Zinc (a) $5 \mathrm{~kg} \mathrm{ha}^{-1}$ with $100 \%$ NPK in maize did not respond significantly to the wheat grain yield over $100 \%$ NPK, suggesting that applied $\mathrm{Zn}$ was used by maize crop to a greater extent. Although treatment $100 \%$ NPK, 50\% NPK, 100\% NPK+FYM@ $5 \mathrm{t} \mathrm{ha}^{-1}$ and 50\% NPK+FYM@ $5 \mathrm{t} \mathrm{ha}^{-1}$ received the same dose of NPK in wheat crop however increased NPK level from 50 to $100 \%$ NPK alone or with FYM in previous maize crop led to the significant increase in wheat grain yield.

\subsection{Effect of chemical fertilizers and FYM on nutrient uptake by maize-wheat system}

Total N, P, K and Zn uptake by the maize-wheat system under different NPK chemical fertilizer and FYM application either alone or jointly (Table 3 ) influenced significantly and varied from

Table 3: Grain yield of maize and wheat and nutrient uptake by system after 4 years of maize-wheat cropping system

\begin{tabular}{|c|c|c|c|c|c|c|c|c|c|c|}
\hline \multirow{3}{*}{ Treatment } & \multicolumn{6}{|c|}{ Grain yield $\left(\mathrm{t} \mathrm{ha}^{-1}\right)$} & \multicolumn{4}{|c|}{$\begin{array}{l}\text { Nutrient uptake }\left(\mathrm{kg} \mathrm{ha}^{-1}\right) \text { by maize- } \\
\text { wheat system }\end{array}$} \\
\hline & \multicolumn{3}{|c|}{ Maize } & \multicolumn{3}{|c|}{ Wheat } & & & & \\
\hline & $\begin{array}{l}\text { Initial } \\
\text { year }\end{array}$ & $4^{\text {th }}$ year & $\begin{array}{c}\text { Over the } \\
\text { years }(2014- \\
2017)\end{array}$ & $\begin{array}{c}\text { Initial } \\
\text { year }\end{array}$ & $4^{\text {th }}$ year & $\begin{array}{c}\text { Over the } \\
\text { years }(2014- \\
2017)\end{array}$ & $\mathrm{N}$ & $\mathrm{P}$ & $\mathrm{K}$ & $\mathrm{Zn}$ \\
\hline NPK* & $5.11^{\mathrm{bc}}$ & $5.21^{b}$ & $5.19^{b}$ & $4.60^{\mathrm{b}}$ & $4.75^{\mathrm{c}}$ & $4.67^{\mathrm{b}}$ & $288.0^{\mathrm{c}}$ & $56.0^{\mathrm{b}}$ & $166.0^{\mathrm{b}}$ & $0.66^{\mathrm{c}}$ \\
\hline $\mathrm{NPK}^{* *}$ & $4.73^{\mathrm{de}}$ & $4.55^{\mathrm{c}}$ & $4.87^{\mathrm{c}}$ & $4.38^{\mathrm{c}}$ & $4.26^{\mathrm{d}}$ & $4.22^{\mathrm{c}}$ & $241.0^{\mathrm{d}}$ & $45.0^{\mathrm{d}}$ & $141.0^{\mathrm{d}}$ & $0.52^{\mathrm{g}}$ \\
\hline FYM*+ Azotobacter & $4.85^{\mathrm{d}}$ & $4.64^{\mathrm{c}}$ & $4.73^{\text {cd }}$ & $3.96^{\mathrm{e}}$ & $3.76^{\mathrm{f}}$ & $3.84^{\mathrm{d}}$ & $217.0^{\mathrm{e}}$ & $39.0^{\mathrm{e}}$ & $128.0^{\mathrm{e}}$ & $0.60^{\mathrm{d}}$ \\
\hline $\begin{array}{l}\text { Cowpea with FYM* }+ \\
\text { Azotobacter }\end{array}$ & $4.68^{\mathrm{de}}$ & $4.56^{\mathrm{c}}$ & $4.59^{\mathrm{de}}$ & $4.12^{\mathrm{d}}$ & $3.94^{\mathrm{e}}$ & $3.98^{\mathrm{d}}$ & $235.0^{\mathrm{d}}$ & $44.0^{\mathrm{d}}$ & $133.0^{\mathrm{e}}$ & $0.58^{\mathrm{d}}$ \\
\hline $\mathrm{NPK}^{*}+\mathrm{FYM} * *$ & $5.33^{\mathrm{a}}$ & $5.54^{\mathrm{a}}$ & $5.48^{\mathrm{a}}$ & $4.82^{\mathrm{a}}$ & $5.16^{\mathrm{a}}$ & $5.06^{\mathrm{a}}$ & $340.0^{\mathrm{a}}$ & $60.0^{\mathrm{a}}$ & $179.0^{\mathrm{a}}$ & $0.70^{\mathrm{b}}$ \\
\hline $\mathrm{NPK}^{* *+\mathrm{FYM}^{* *}}$ & $5.06^{\mathrm{c}}$ & $5.28^{b}$ & $5.16^{\mathrm{b}}$ & $4.61^{b}$ & $4.73^{c}$ & $4.65^{b}$ & $281.0^{\mathrm{c}}$ & $48.0^{\mathrm{c}}$ & $153.0^{\mathrm{c}}$ & $0.60^{\mathrm{de}}$ \\
\hline $\mathrm{NPK}^{*}+5 \mathrm{~kg} \mathrm{Zn}$ & $5.20^{\mathrm{abc}}$ & $5.34^{\mathrm{b}}$ & $5.38^{\mathrm{a}}$ & $4.77^{\mathrm{a}}$ & $4.92^{b}$ & $4.80^{b}$ & $303.0^{\mathrm{b}}$ & $55.0^{\mathrm{b}}$ & $161.0^{\mathrm{b}}$ & $0.78^{\mathrm{a}}$ \\
\hline FYM** & $4.59^{e}$ & $4.27^{\mathrm{d}}$ & $4.55^{\mathrm{e}}$ & $3.80^{\mathrm{f}}$ & $3.59^{\mathrm{g}}$ & $3.51^{\mathrm{e}}$ & $189.0^{\mathrm{f}}$ & $37.0^{\mathrm{e}}$ & $115.0^{\mathrm{f}}$ & $0.48^{\mathrm{h}}$ \\
\hline Control & $4.23^{\mathrm{f}}$ & $3.67^{\mathrm{e}}$ & $3.88^{\mathrm{f}}$ & $3.54^{\mathrm{g}}$ & $3.24^{\mathrm{h}}$ & $3.33^{\mathrm{f}}$ & $170.0^{\mathrm{g}}$ & $30.0^{\mathrm{f}}$ & $102.0^{\mathrm{g}}$ & $0.37^{\mathrm{i}}$ \\
\hline Initial & 0.06 & 0.05 & 0.05 & 0.04 & 0.05 & 0.05 & 3.5 & 0.9 & 2.3 & 0.01 \\
\hline $\mathrm{SEm} \pm$ & 0.18 & 0.16 & 0.15 & 0.12 & 0.15 & 0.16 & 10.6 & 2.6 & 6.8 & 0.02 \\
\hline
\end{tabular}

NPK*- 100\% NPK, NPK**- 50\% NPK, FYM*-FYM 10 t ha $^{-1}$, FYM $^{* *}$ - FYM 5 t ha 


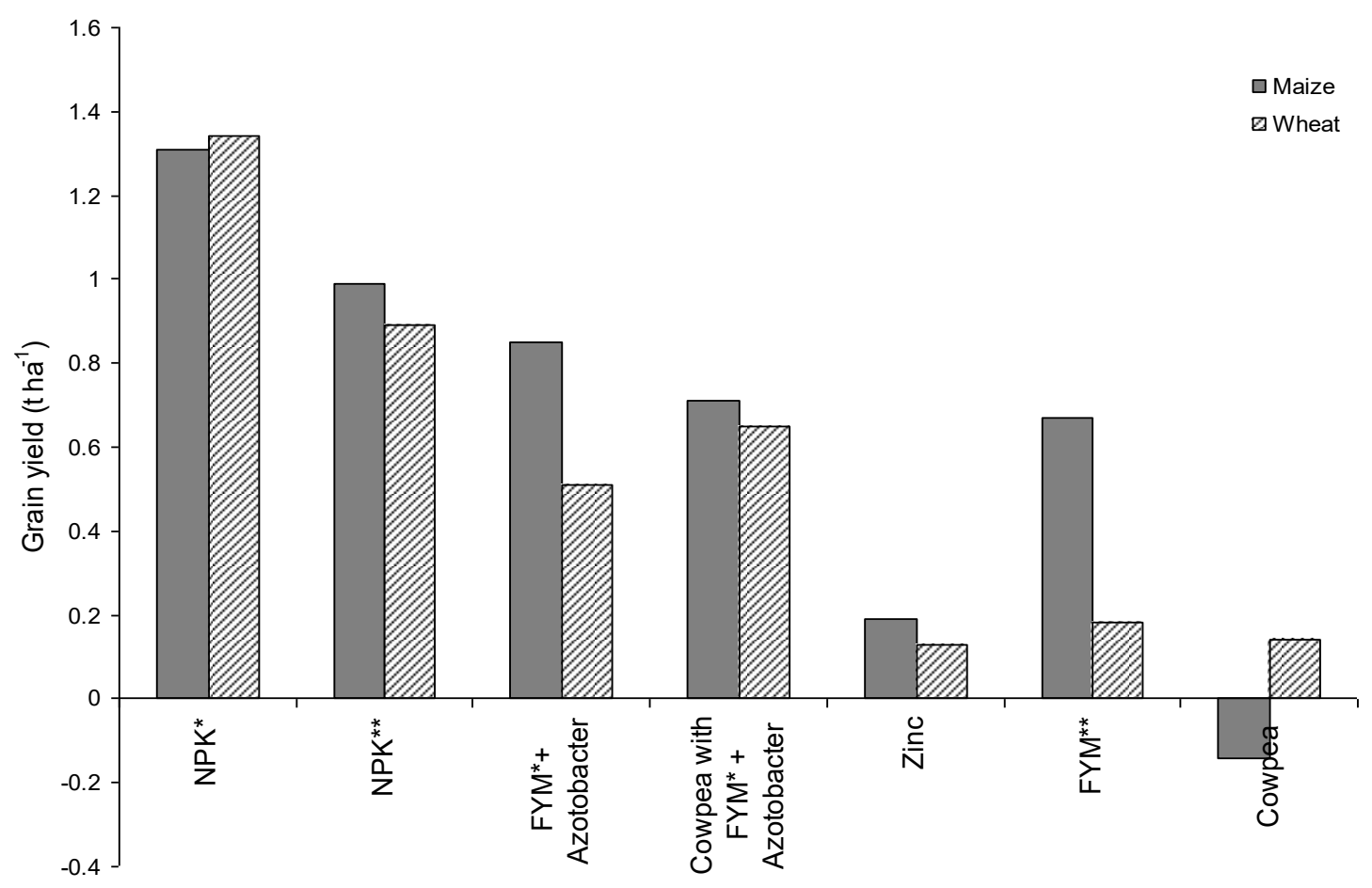

Figure 2 Response of grain yields of maize and wheat to different doses of fertilizers, FYM and their combinations

170.0-339.4, 30.3-60.1, 102.0-178.9 and 0.369-0.775 $\mathrm{kg} \mathrm{ha}^{-1}$, respectively. The highest uptake of $\mathrm{N}, \mathrm{P}$ and $\mathrm{K}$ by the system was recorded under 100\% NPK + FYM @ 5t ha ${ }^{-1}$ (Brar et al., 2002) followed by $100 \%$ NPK while highest removal of $\mathrm{Zn}$ was with $100 \% \mathrm{NPK}+\mathrm{Zn} @ 5 \mathrm{~kg} \mathrm{ha}{ }^{-1}$ followed by $100 \% \mathrm{NPK}+$ FYM@5t ha ${ }^{-1}$, however, the system removed the least amount of nutrients under controlled condition. The highest uptake of $\mathrm{N}$, $\mathrm{P}$ and $\mathrm{K}$ in $100 \% \mathrm{NPK}+\mathrm{FYM} @ 5 \mathrm{t} \mathrm{ha}^{-1}$ was due to the application of balance amount of $\mathrm{N}, \mathrm{P}$ and $\mathrm{K}$ which supplied better nutrients content to the crop moreover during the decomposition of FYM, incorporated additional amount of nutrients into the soil matrix as well as helps to release and become available for plants (Ram et al., 2016; Meena et al., 2018). Significantly lower $\mathrm{Zn}$ withdrawal in $\mathrm{Zn}$ omitted treatments compared with $\mathrm{Zn}$ treatment suggested that continuous cropping with a different combination of NPK fertilizer and FYM without $\mathrm{Zn}$ led to lesser removal of $\mathrm{Zn}$ (Singh \& Ram, 2005). More uptakes of N, P, and $\mathrm{K}$ was noticed with increasing NPK fertilizer dose with FYM from sub-optimal to optimal as compared to without FYM and cowpea intercropping with FYM over without intercropping. This shows that FYM inclusion with NPK with maize crop did respond more to nutrients removal as compared to sole NPK or FYM with legume intercropping by the system.

\subsection{Response of grain yield of maize and wheat to chemical fertilizers and FYM}

During the four years of continuous application of NPK fertilizers, biofertilizer, FYM, and their combinations in maize and wheat crops, the response of maize and wheat grain yields to nutrient management was diverse and in general positive (Figure 2). This was owing to marked variation in the nutrient availability to the crops supplied by different combinations of NPK fertilizer, biofertilizer, and FYM. Results also indicated that wheat in terms of yield responded $2.8-40.2 \%$ more as compared to maize (-3.0 to $33.8 \%$ ) under different nutrient management practices. Maximum yield response was obtained with $100 \%$ NPK followed by $50 \%$ NPK for both crops while least with cowpea intercropping and zinc for maize and wheat, respectively. This was attributed to the fact that a higher supply of N, P, and K through NPK fertilizer in both crops led to greater availability of nutrients than other sources. However, no marked differences in yield response of 25.5 and $26.7 \%$ for 50\% NPK, 18.3 and 19.5\% for cowpea with FYM @ 10t $\mathrm{ha}^{-1}+$ Azotobacter and 3.7 and 2.8\% for Zn@5 $@ \mathrm{~kg} \mathrm{ha}^{-1}$ were recorded for maize and wheat, respectively, indicating that both crops are almost equally responsive to these nutrients. For the maize grain yield, cowpea intercropping produced slightly negative yield response $\left(-0.14 \mathrm{t} \mathrm{ha}^{-1}\right)$ as the cowpea was competitive for nutrients and sunlight against maize but the incorporation of 
cowpea biomass and $\mathrm{N}$ fixation increased yield response to the succeeding wheat crop $\left(0.14 \mathrm{tha}^{-1}\right)$. The yield response trend for different nutrient management practices was recorded in the increasing order of cowpea intercropping, Zn@5 $\mathrm{kg} \mathrm{ha}{ }^{-1}$, FYM @ 5t ha ${ }^{-1}$, cowpea with FYM@10t ha ${ }^{-1}+$ Azotobacter, FYM @ 10t $\mathrm{ha}^{-1}+$ Azotobacter, 50\% NPK , and 100\% NPK for maize and Zn $5 \mathrm{~kg} \mathrm{ha}{ }^{-1}$, cowpea intercropping FYM@5 $\mathrm{t} \mathrm{ha}^{-1}$, cowpea with FYM@10t ha ${ }^{-1}+$ Azotobacter, FYM @10t ha ${ }^{-1}+$ Azotobacter $50 \%$ NPK and $100 \%$ NPK for wheat.
3.7 Relationship between the yield of maize and wheat with soil organic carbon and pool

The regression analysis revealed the positive relationship between the yield of maize and wheat with SOC and SOC pool (Figure 3a $\& 3 b$ ). During the four years, the grain yield of maize and wheat owing to different fertilizer management practices varied from $38.6-60.2 \%$ and $28.5-49.6 \%$ by SOC content and SOC pool/storage, respectively. The maize grain yield altered more by
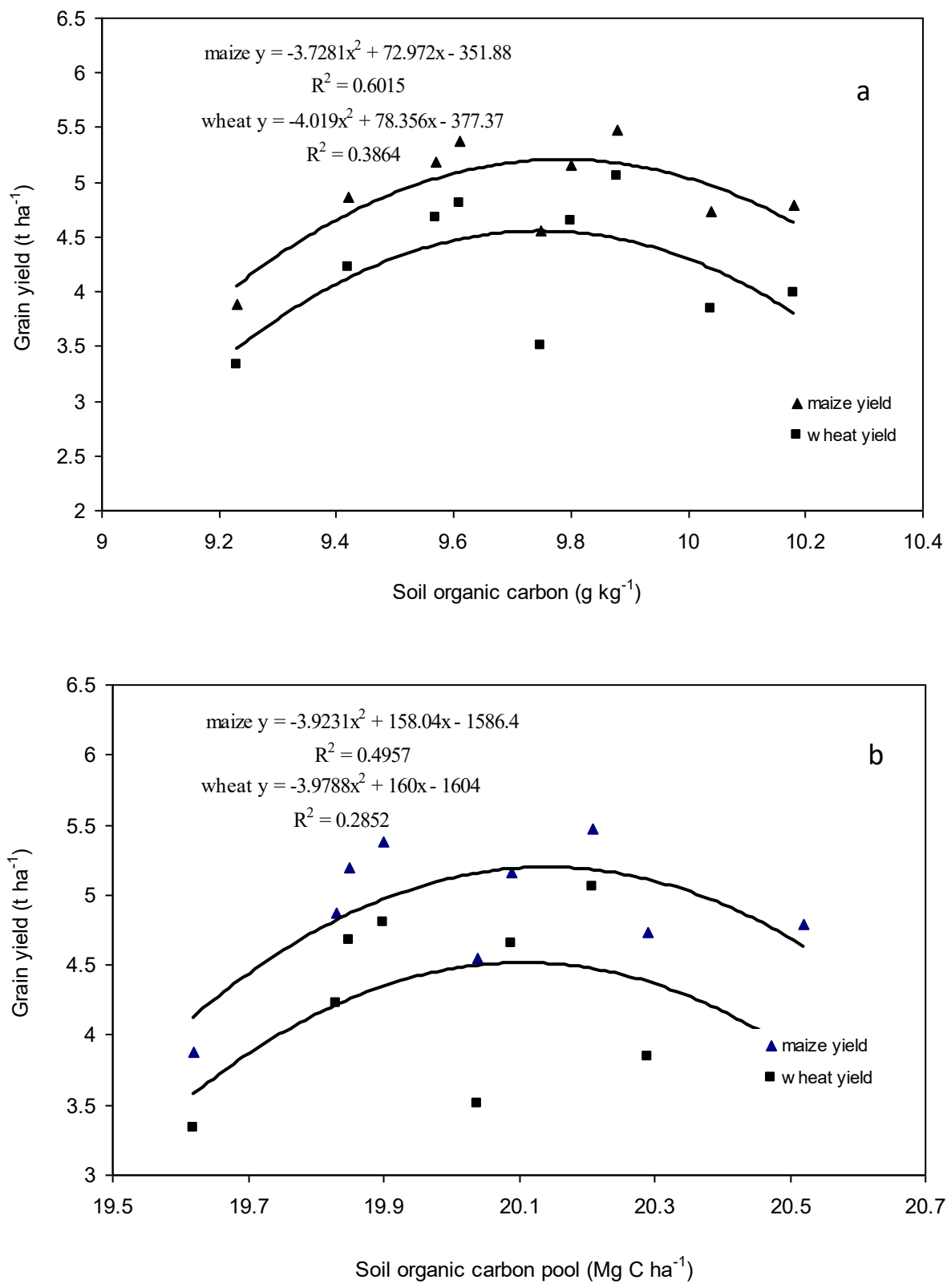

Figure 3 Relationship between grain yield of maize and wheat and soil organic carbon and soil organic carbon pool in a maize-wheat cropping system 
soil organic carbon as $\mathrm{R}^{2}$ value $(0.6015)$ fitted good between maize grain yield and SOC, however $\mathrm{R}^{2}$ values were found low between wheat grain yield and SOC $(0.3864)$ and between SOC pool and grain yield of maize $(0.4957)$ and wheat $(0.2852)$ which emphasizes the significance of SOC for maize yield. The coefficient of determination $\left(\mathrm{R}^{2}\right)$ also indicated more influence of SOC and SOC pool on maize than wheat yield. Thus higher the content of SOC and SOC pool in mollisol, more is the yield of maize compared to wheat.

\section{Conclusion}

Over the years, continuous application of a recommended dose of NPK fertilizers with FYM @ $5 \mathrm{t} \mathrm{ha}^{-1}$ brought out a marked increase in productivity and nutrient uptake by maize and wheat that enhanced the soil organic carbon content and sequestration in maize-wheat rotation in a mollisol hence may be the best option for higher crop yields. However organic mode of nutrient application almost failed to sustained yield. Cowpea intercropped maize with FYM@10t ha ${ }^{-1}$ also not suitable as it reduced the grain yield of maize however may be beneficial for succeeding wheat crop as it increased soil organic carbon. Incorporation of farmyard manure@ 5 t ha ${ }^{-1}$ along with a half dose of recommended NPK fertilizer in maize crop accomplished grain yield at par with $100 \%$ NPK fertilizer for both the crops. Use of half dose of recommended nutrients, state practice (farmyard manure @ $5 \mathrm{t} \mathrm{ha}^{-1}$ ), and control led to a reduction in the crop yields and SOC sequestration rates.

\section{Acknowledgment}

The authors would like to express great thanks to the Indian Council for Agricultural Research (ICAR) for the financial support for this study.

\section{Conflict of interest}

The authors declare that they have no conflict of interest

\section{References}

Achieng JO, Ouma G, Odhiambo G, Muyekho F (2010) Effect of farmyard manure and inorganic fertilizers on maize production on alfisols and ultisols in Kakamega, western Kenya. Agriculture and Biology Journal of North America 1: 430-439.

Alla WAH, Shalaby EM, Dawood RA, Zohry AA (2014) Effect of cowpea (Vigna sinensis L.) with maize (Zea mays L.) intercropping on yield and its components. International Journal of Agricultural and Biological Engineering 8: 1258-1264.

Annual Progress Report (2016) Indian Institute of Maize Research, PAU Campus, Ludhiana, Punjab, India
Baral BR, Adhikari P (2013) Eeffect of Azotobacter on growth and yield of maize. SAARC Journal of Agriculture 11: 141-147.

Benbi DK, Senapati N (2009) Soil aggregation and carbon and nitrogen stabilization in relation to residue and manure application in rice-wheat systems in northwest India. Nutrient Cycling in Agroecosystems 87: 233-247.

Bi L, Zhang B, Liu G, Li. Z, Liu Y, Ye C, Yu X, Lai T, Zhang J, Yin J, Yin L (2009) Long-term effects of organic amendments on the rice yields for double rice cropping systems in subtropical China. Agriculture, Ecosystems \& Environment 129: 534-541.

Blair N, Faulkner RD, Till AR, Poulton PR (2006) Long-term management impacts on soil $\mathrm{C}, \mathrm{N}$ and physical fertility. Part I: broad balk experiment. Soil \& Tillage Research 91: 30-38.

Blake GR, Hartze KH (1986) Methods of Soil Analysis. Part 1. Physical and Mineralogical Methods ( $2^{\text {nd }}$ ed.), In: Klute A (Ed). American Society of Agronomy: Madison, Wisconsin; Agronomy Monograph. 9: 363-375.

Brar BS, Chhina HS, Randhawa PS, Dhillon NS, Benipal DS (2002) Long-term effects of organic and inorganic fertilizers use on $\mathrm{N}$ availability under intensive cropping system. Paper presented in $17^{\text {th }}$ WCSS, 21-24 August, 2002, Thailand, Symposium no.13 and paper no 1233

Brar BS, Singh J, Singh G, Kaur G (2015) Effects of long term application of inorganic and organic fertilizers on soil organic carbon and physical properties in maize-wheat rotation. Agronomy 5: 220-238.

Chaudhary S, Dheri GS, Brar BS (2017) Long-term effects of NPK fertilizers and organic manures on carbon stabilization and management index under rice-wheat cropping system. Soil \& Tillage Research 166: 59-66

Deshpande SB, Feheranbacher TB, Beavers AH, Ray BW (1971) Mollisols of Tarai region of Uttar Pradesh, Northern India. II. Genesis and classification. Geoderma 6: 195-201.

Dubey V K, Patel A K, Shukla A, Shukla S, Singh S (2012). Impact of continuous use of chemical fertilizer. International Journal of Engineering Research and Development 3: 13-16.

Egbe OM, Alibo SE, Nwueze I (2010) Evaluation of some extraearly and early- maturing cowpea varieties for intercropping with maize in southern Guinea Savannah of Nigeria. Agriculture and Biology Journal of North America 1: 845-858.

Hamd Alla WA, Shalaby EM, Dawood RA, Zohry AA (2014) Effect of cowpea (Vigna sinensis L.) with maize (Zea mays L.) 
intercropping on yield and its components. International Journal of Agricultural and Biological Engineering 8: 1258-1264.

Hanway JJ, Heidel H (1952) Soil analysis methods as used in Iowa state college of soil testing laboratory. Iowa State College of Agriculture 57:1-31.

Jackson ML (1973) Soil Chemical Analysis, Prentice Hall of India Pvt. Ltd., New Delhi.

Kang GS, Beri V, Sidhu BS, Rupela OP (2005) A new index to assess soil quality and sustainability of wheat-based cropping systems. Biology and Fertility of Soils 41: 389-398.

Kher D (1993) Effect of continuous liming, manuring and cropping on DTPA extractable micronutrients in an Alfisol. Journal of the Indian Society of Soil Science 41: 366-367.

Kumari G, Thakur SK, Kumar N, Mishra B (2013) Long term effect of fertilizer, manure and lime on yield sustainability and soil organic carbon status under maize (Zea mays)-wheat (Triticum aestivum) cropping system in alfisols. Indian Journal of Agronomy 58: 152-158.

Lindsay WL, Norvell WA (1978) Development of DTPA soil test for zinc, iron, manganese and copper. Soil Science Society of America Journal 42: 421-428.

Manna MC, Swarup A, Wanjari RH, Ravankar HN, Mishra B, Saha MN, Singh YV, Sahi DK, Sarap PA (2005) Long-term effect of fertilizer and manure application on soil organic carbon storage, soil quality and yield sustainability under sub-humid and semi-arid tropical India. Field Crops Research 93: 264-280.

Meena HM, Sharma RP, Sankhyana NK, Sepehya S (2017) Effect of continuous application of fertilizers, farmyard manure and lime on soil fertility and productivity of the maize-wheat system in an acid alfisol. Communications in Soil Science and Plant Analysis 48: 1552-1563.

Meena KB, Alam SM, Singh H, Bhat MA, Singh AK, Mishra AK, Thomas $T$ (2018) Influence of farmyard manure and fertilizers on soil properties and yield and nutrient uptake of wheat. International Journal of Chemical Studies 6: 386-390.

Mongare PO, Okalebo JR, Othieno CO, Ochuodho JO, Njoroge R, Otinga AN (2020).Effect of cropping cystem and nitrogen on maize and soybean yields in Western Kenya. Sustainable Agriculture Research 9:39-48.

Naresh RK (2013) Rice residues: From waste to wealth through environment friendly and innovative management solutions, it's effects on soil properties and crop productivity. International Journal of Life Sciences Biotechnology and Pharma Research 2: 133-141.
Ndiso JB, Chemining'wa GN, Olubayo FM, Saha HM (2018) Effect of different farmyard manure levels on soil moisture content, canopy temperature, growth and yield of maize-cowpea intercrops. Journal of Advanced Studies in Agricultural, Biological and Environmental Sciences 5: 5-21.

Olsen SR, Cole CU, Watanabe FS, Deen LA (1954) Estimation of available phosphorus in soil by extracting with sodium bicarbonate (USDA Circular 939). Washington, DC: US Government Printing Office.

Panneerselvam S, Lourduraj AC, Balasubramanian N (2000) Soil available phosphorus and its uptake by soybean (Glycine max, L. Merrill) as influenced by organic manures, inorganic fertilizers, and weed management practices. Indian Journal of Agricultural Research 34: 9-16.

Panwar AS, Shamim M, Babu S, Ravishankar N, Prusty AK, Alam NM, Singh DK, Bindhu JS, Kaur J, Dashora LN, Latheef Pasha MD, Chaterjee S, Sanjay MT, Desai LJ (2019). Enhancement in productivity, nutrients use efficiency, and economics of rice-wheat cropping systems in India through farmer's participatory approach. Sustainability 11: 2-26.

Pareek N, Yadav BL (2011) Effect of organic manures on soil physicochemical properties, soil microbial biomass and yield of mustard under irrigation of different residual sodium carbonate waters. Journal of the Indian Society of Soil Science 59:336-342

Peng SH, Wan-Azha WM, Wong WZ, Go WZ, Chai EW, Chin, KL, H'ng PS (2013) Effect of using agro-fertilizers and N-fixing azotobacter enhanced biofertilizers on the growth and yield of corn. Journal of Applied Sciences 13: 508-512.

Pillai MP, Duaisamy S, Myleramy G (2006) Long-term fertilization on sustenance of high production farming in an Inceptisol. The 18th World Congress of Soil Science, held at Philadelphia, PA on July 9-15, 2006, Pp146-148.

Rahman KMA, Zhang D (2018). Effects of fertilizer broadcasting on the excessive use of inorganic fertilizers and environmental sustainability. Sustainability 10: 1-15.

Ram S, Singh V, Sirari P (2016) Effects of 41 years of application of inorganic fertilizers and farm yard manure on crop yields, soil quality, and sustainable yield index under a rice-wheat cropping system on Mollisols of North India. Communications in Soil Science and Plant Analysis 47: 179-193.

Rasool R, Kukal S, Hira G (2008) Soil organic carbon and physical properties as affected by long-term application of FYM and inorganic fertilizers in maize-wheat system. Soil \& Tillage Research 101: 31-36. 
Saini JP, Kumar R (2014) Long term effect of organic sources of nutrients on productivity and soil health in maize+soybeanwheat+gram cropping system. Rahmann G \& Aksoy U (Eds.) Proceedings of the 4th ISOFAR Scientific Conference. 'Building Organic Bridges', at the Organic World Congress 2014, 13-15 Oct., Istanbul, Turkey.

Sharma S, Padbhushan R, Kumar U (2019) Integrated nutrient management in rice-wheat cropping system: An evidence on sustainability in the Indian subcontinent through meta-analysis. Agronomy 9: 2-15.

Singh V, Ram N (2005) Effect of 25 years of continuous fertilizer use on response to applied nutrients and uptake of micronutrients by rice-wheat-cowpea system. Cereal Research Communications 33: 589-594.

Soleimanzadeh H, Gooshchi F (2013) Effects of azotobacter and nitrogen chemical fertilizer on yield and yield components of wheat (Triticum aestivum L.). World Applied Sciences Journal 21: 1176-1180.

Subbiah BV, Asija GL (1956) A rapid procedure for the estimation of available $\mathrm{N}$ of soils. Current Science 25:259-260.

Takim FO (2012) Advantages of maize-cowpea intercropping over sole cropping through competition indices. Journal of Agriculture and Biodiversity Research 1: 53-59.

Tiwari KN (2003) Phosphorus. In Fundamentals of Soil Science, Indian Society of Soil Science (IARI), Indian Agricultural Research Institute, New Delhi, India, 353-368.
Tolanur SR, Badanur VP (2003) Changes in organic carbon, available $\mathrm{N}, \mathrm{P}$, and $\mathrm{K}$ under integrated use of organic manure, green manure, and fertilizers on sustaining productivity of pearl millet-pigeon pea system and fertility of an Inceptisol. Journal of the Indian Society of Soil Science 51:254-57.

Tripathi R, Nayaka AK, Bhattacharyya P, Shukla AK, Shahid M, Raja R, Panda BB, Mohanty S, Kumar A, Thilagama VK (2014) Soil aggregation and distribution of carbon and nitrogen in different fractions after 41 years long-term fertilizer experiment in tropical rice-rice system. Geoderma 213:280-286.

Urkurkar JS, Tiwari A, Chitale S, Bajpai RK (2010) Influence of long-term use of inorganic and organic manures on soil fertility and sustainable productivity of rice (Oryza sativa) and wheat (Triticum aestivum) in inceptisols. Indian Journal of Agricultural Sciences 80: 208-212.

Yadav RL, Subba Rao AVM (2001) Atlas of cropping systems in India. Project Directorate for Cropping Systems Research, Modipuram, Meerut, India. Bulletin No 2001-2, pp. 96

Yang ZC, Zhao N, Huang F, Lv. YZ (2015) Long-term effects of different organic and inorganic fertilizer treatments on soil organic carbon sequestration and crop yields on the North China Plain. Soil \& Tillage Research 146: 47-52.

Zhang S, Yang X, Wiss M, Grip H, Lövdahl L (2006) Changes in physical properties of a loess soil in China following two longterm fertilization regimes. Geoderma 136: 579-587. 